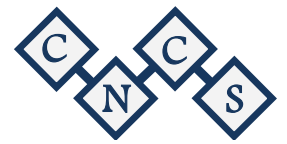

\title{
Community Development Training with Eco-print Training Wukirsari Village, Sleman District, Indonesia
}

\author{
Tri Mardiana ${ }^{1}$, A.Y.N. Warsiki ${ }^{2}$ and Sucahyo Heriningsih ${ }^{3}$ \\ 1,2 Manajement Department, Economic and Business Faculty, Universitas Pembangunan Nasional \\ "Veteran" Yogyakarta, Indonesia \\ ${ }^{3}$ Accounting Department, Economic and Business Faculty, Universitas Pembangunan Nasional "Veteran" \\ Yogyakarta, Indonesia \\ IItriana_upn@yahoo.com.sg, ${ }^{2} k i k i \_u p n @ y a h o o . c o . i d,{ }^{3}$ heriningsih_s@yahoo.co.id
}

\begin{abstract}
This community empowerment aims to explore the natural potential of the village of Wukirsari, Sleman Regency, as well as develop the village's creative economy through ecoprint training, as a vehicle for the village's creative economy based on leaf potential. The training method using various references and empowering the community to make ecoprints was followed by 15 mothers who were representatives of the joint business group. The results of this community empowerment produce village potential namely leaves, and training approaches by studying the conditions and rural life of, with, and by village communities. The concept of the ecoprint training approach emphasizes community involvement in all activities. The community is involved in the planners and implementers of the ecoprint training program and not just as an audience in ecoprint making training. The results of the ecoprint training are expected to increase the creative economy that has the potential to be developed by villagers, as a form of participation in building village businesses, and to be able to provide welfare for the residents of their village.
\end{abstract}

Keywords: Village Potential, Eco-print Training, Wukirsari Village, Development Training.

\section{INTRODUCTION}

Community economic development is currently being promoted by the Indonesian government, this is evidenced by the sight of several economic improvement programs that have been provided by the government, such as "joint business group programs", "home industry programs", and many other programs aimed at improving community economy, to reduce poverty, and increase income and social welfare of community families. One effort to support government programs through the "creative economy" by providing Micro and Small Business Training is "Ecoprint" in intensifying creative economic endeavors by using the natural potential of the leaf media. This micro and medium business training was held to foster the interest of entrepreneurs in improving the village economy, especially in the development of ecoprint batik, which is a characteristic that elevates culture, especially in traditional Indonesian culture.
The government focuses on developing creative industries by fixing various factors from upstream and downstream, starting from human resources and ecosystems. The success of the development of the creative economy is influenced by two determining factors, namely humans (actors) and the development of environmentally friendly ecosystems. The strategy of developing a creative economy is aimed at strengthening these two factors. The government continues to boost the quality of human resource creativity as this has become an important element in this program. People must be creative first, and this requires an active role from ministries, institutions and local governments to socialize it with the right program, one of which is through community empowerment in collaboration with universities in an effort to support the creative economy in the village by utilizing the natural potential in village namely the potential of the leaf.

By seeing the existing potential, the ecoprint training aims to take advantage of the natural 
potential of the village, based on local potential. Social change is a change that is expected to create a better life for the village community, and is carried out by the community themselves. This means that the community will be mobilized and encouraged to be able to recognize and explore their potential. This means that the community conducts its own activities starting from the planning process to the implementation while simultaneously monitoring and evaluating these activities. Thus the community must dare to act continuously to improve the quality and standard of living and dignity of themselves, their families and their environment. The training on making ecoprints will encourage the community to understand well, recognize the needs and abilities of their villages, so that a business opportunity will be created capable of achieving the economic empowerment of rural communities.

\section{LITERATURE REVIEW}

\section{A. Community Development}

Community empowerment is a process that develops and strengthens the ability of the community to continue to be involved in the development process that takes place dynamically so that the community can solve the problems faced and can make decisions freely (independently) and independently (Fatterman, 1996). The process of community empowerment is an effort to help the community to develop their own abilities so that they are free and able to overcome problems and make decisions independently. The empowerment process is carried out by giving authority (power), accessibility to resources and an accommodating environment (Zimmerman, 1996).

The community empowerment approach embodied in participatory development is very appropriate and can be used to anticipate changes in the community and its strategic environment. As the basic concept of participatory development is to carry out development efforts on the basis of meeting the needs of the community itself so that the community is able to develop and overcome its own problems independently, sustainably and sustainably. There is no social research that will be able to bring about an improvement in the existing social conditions as long as researchers position themselves as experts who stand outside the social reality under study, and treat the people being studied as objects that only live passively existing social reality. Researchers must place themselves as part of the community being studied and view the citizens being studied as subjects who have the moral right to regulate their lives, and have the desire and ability to do so.

In the end, it is hoped that the community will be able to jointly decide on various types of businesses that have the potential to be developed as a form of participation in building a business. Thus will be born a sense of belonging and responsibility to advance the business and be able to provide welfare for residents of his village. The community empowerment approach embodied in participatory development is very appropriate and can be used to anticipate changes in the community and its strategic environment. As the basic concept of participatory development is to carry out development efforts on the basis of meeting the needs of the community itself so that the community is able to develop and overcome its own problems independently, sustainably and sustainably. The decision to examine a community with the aim of bringing improvements into the community, through among other things community empowerment, is already an evaluation result. Based on the results / review of secondary data on the profile of Wukirsari village, including a brief area map and field observations, direct field observations / observations, interviews with Wukirsari village and community officials, mapping of village potential, case studies by looking at local history, and biography and results from a simple, short questionnaire. So development efforts are made on the basis of meeting the needs of the community itself so that the community is able to develop and overcome its own problems independently, continuously and sustainably by providing ecoprint training. The following are photos of training implementation and community empowerment:

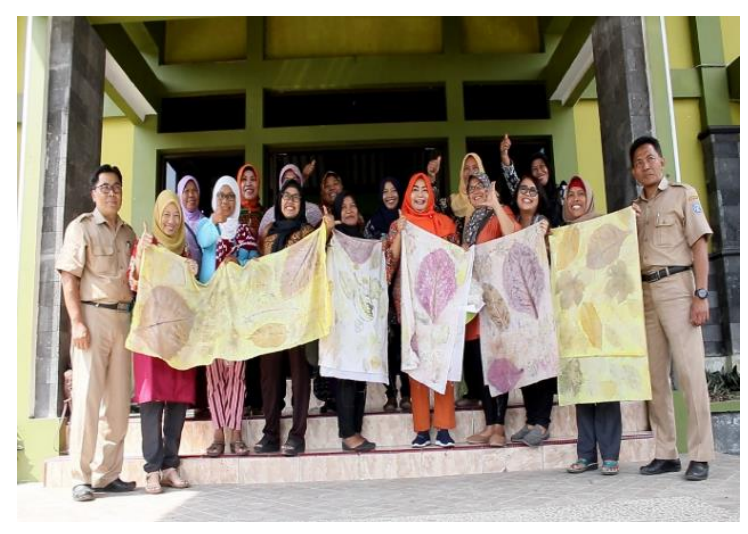




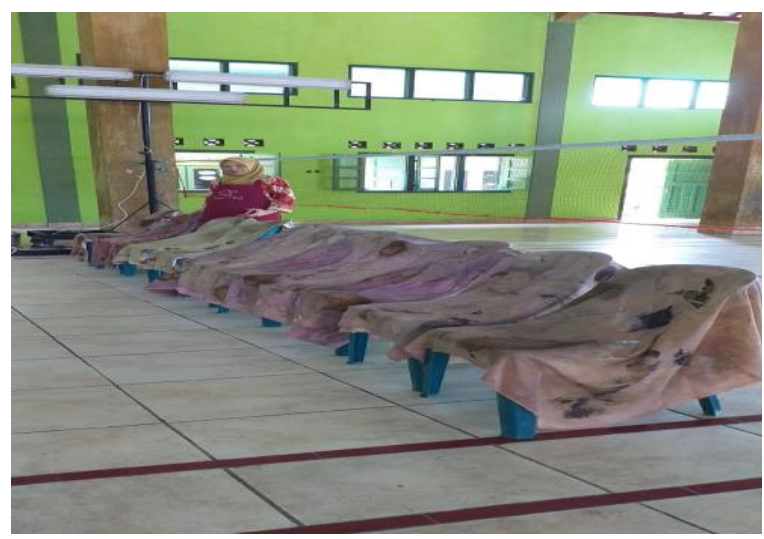

\section{TRAINING METHOD}

Ecoprint training is a training by applying the village potential development model, in the form of leaves and plants that grow and are found in many villages, through the creative economy "Ecoprint" is expected to increase the income of the people of Wukirsari Village, Cangringan District, Sleman Regency. The training was started by identifying the village's potential and community empowerment through training in making ecoprints. This ecoprint training was carried out using the method of assessing the situation of the village quickly, and in practice it involved many villagers.

\section{RESULT AND DISCUSSION}

\section{A. Definition of Eco Printing}

The ecoprint technique can be defined as a natural coloring technique while at the same time giving motifs to fabrics that are quite simple but can create unique and interesting visuals. The principle of manufacture is through direct contact between leaves, flowers, other plant parts that contain color pigments with certain fabric materials. Because it is made with natural materials, the resulting fabric motif will usually always be different even though it still uses the same type of leaves from plants. The colors and motifs printed on the fabric will also generally have exclusive characteristics depending on the geographical location of the originating plant.

\section{B. Plants for Eco Printing}

To determine whether a plant can be used as coloring in eco printing or not, you can test it based on the aroma, color of the plant and its water content. This water content greatly influences the success of the eco printing process. Plants that emit a sharp scent are one indication that these plants can be used as natural dyes. Rub the leaves by hand or on a cloth surface. When plants leave stains, the leaves have the potential to be used as natural dyes. Soak the leaves in hot water for 10 minutes. When the water changes color, this plant also has the potential to become a natural coloring agent. From various techniques applied in eco printing, in principle there are many benefits that can be obtained.

\section{Some practical benefits of eco printing techniques include:}

The media used in Ecoprint is not limited to fabric, but anything that is able to absorb the natural color of the leaves and flowers can be used. Compared to plain cloth or patterned with digital printing techniques cloth products produced with eco printing techniques are far more exclusive. In addition to the exclusive looking design, ecoprinting products are also more impressed with good looking and classy looks. Eco printing can be used as an alternative way to reduce environmental and ecosystem damage due to chemical waste in textile factories. Because many eco printing people have not been involved with it, it has become a promising business opportunity because there are still few competitors. The capital spent on making eco printing products is not so much, whereas if the coloring is just taking it in nature. Design innovation in the field of eco printing is very flexible, and you can continue to improve product quality by developing techniques continuously.

\section{Stage of the Ecoprinting}

Process Preparing Fabrics:

1. Scouring (cooking): Scouring is part of the fabric preparation process so that the constituent components of fibers in the form of oil, grease, wax, dirt from the fabric attached to the surface of the fiber can be removed, making it easier for the absorption of dyes on the fabric fiber.

2. The method is the fabric that will be used soaked in TRO for 1 hour, then squeezed and rinsed. Mordanting. Mordanting is a fabric boiling process. Mordanting plays an important role in preparing fabric so that it can receive dyes well. In order to carry out the mordanting process, in principle, a number of chemicals as mordan substances are needed. 
Some substances commonly used as mordan ingredients include alum and soda ash.

The objectives of the mordanting process are:

a. improves the ability to stick dyes to the fabric

b. remove components in the fabric fibers such as oil, grease, wax and other impurities that can inhibit the entry of dyes into the fabric fibers.

c. as a color enhancer so that the fabric is more resistant to fade

d. increasing the attractiveness of natural dyes to textile materials in order to produce good colorness and sharpness.

e. forming a chemical bridge between natural dyes and fabric fibers so that the attractiveness of dyes increases with fiber.

f. The main function of alum and soda ash as a reinforcement in fabric staining and increased resistance to fire. Mordan material needed for 1 piece of $2 \mathrm{~m}$ fabric is alum as much as 16 grams and soda ash as much as 4 grams.

3. The trick is to boil water until boiling, add alum with soda ash until it dissolves, then a new cloth is inserted and boiled over medium heat for 1 hour and soaked for 8-12 hours, then rinsed and aerated. For silk fabric does not need to be boile.

4. Once you are satisfied with the design you made, then place the cloth soaked with natural dyes on the leaves that have been arranged.

5. Cover the plastic on top of the color fabric, after neatly covered, fold the cloth and the plastic into two equal parts. Roll slowly and strongly.

6. To hold the position so that it is not loosened, wrap a raffia rope along the outside of the fabric roll and tie it tightly.

7. Heat water using steam over a stove over medium heat. Insert a roll of cloth into the steamer, then steam for two hours to move the natural pattern of the leaves to the fabric so that the pigment contained in the plant is extracted perfectly and produces an attractive color.

8. After steaming for two hours, then remove the cloth roll from the steamer then let stand for a few moments until it is completely cold.

9. Finally untie the raffia straps found on the fabric and see the results. The plain white cloth that you have now has been successfully transformed into a beautiful patterned fabric that only exists in the world. Wait for the cloth to dry on its own.

10. After the cloth is stored for a week, then the last process is fixation to bind the color so it does not fade. How to soak a cloth with alum solution ( 2 meters of cloth soaked with 5 grams of alum and 2 liters of water) for $15-30$ minutes, then rinsed and dried with aerated air, not exposed to sunlight

\section{CONCLUSION}

The untapped nature of the natural potential in Cangkringan Village, Sleman Regency, has encouraged ecoprint training. This training can develop skills that provide economic and social benefits for the community by utilizing the natural potential of the village. By increasing the skills of the mothers of the joint venture group, and increasing local economic activities that can indirectly improve the welfare of the village community, because ecoprint products are worth selling so that the community does not only depend on the agricultural sector. The result of this community empowerment activity is the increased capacity of the community in producing ecoprints. It is expected that with this program, the wider community, especially the people of Cangkringan Village, Sleman Regency can make ecoprints and produce it in large numbers so that it can improve the welfare of the household. In addition, with the increasing capacity of the community in making ecoprints, motives or other methods that are also worth selling can be developed so as to improve community welfare.

\section{REFERENCES}

[1] DS, Bayu. Wirawan., \& Alvin, M. A. (2019). Teknik Pewarnaan Alam Eco Print Daun Ubi Dengan Penggunaan Fiksator Kapur, Tawas Dan Tunjung. Jurnal Litbang Kota Pekalongan, 17.

[2] Kharishma, V., \& Septiana, U. (2019). Pelatihan Teknik Ecoprint Untuk Guru Paud. Prosoding: Seni, Teknologi, dan Masyarakat, 2, 183-187.

[3] Lindiawati, L., Sari, L. P., \& Wulandari, D. A. (2018). Sinergi Motif Batik Eco-Print Dan Asesoris Sospeso Untuk Peningkatan Produktifitas UKM Batik Dan UKM. In Seminar Nasional Hasil Pengabdian Kepada Masyarakat (Vol. 2, No. 1, pp. 17-21).

[4] Masyitoh, F., \& Ernawati, E. (2019). Pengaruh Mordan Tawas Dan Cuka Terhadap Hasil Pewarnaan Eco Print Bahan Katun Menggunakan Daun Jati (Tectona Grandis). Gorga Jurnal Seni Rupa, 8(2), 387-391.

[5] Ningrum, T. (2018). Analisis Proses Pembuatan Batik Ecoprint di Rumah Batik 
Balitar Kota Blitar. SKRIPSI Jurusan Seni dan Desain-Fakultas Sastra UM.

[6] Utaminingsih, A., \& Wike, W. (2019). Pelatihan Ecoprint Bagi Kader PKK di Desa Tegalweru, Kecamatan Dau, Kabupaten Malang. Jurnal Pengabdian Kepada Masyarakat, 6(1),28-32.

[7] Sedjati, D. P., \& Sari, V. T. (2019). Mix Teknik Ecoprint Dan Teknik Batik Berbahan Warna Tumbuhan Dalam Penciptaan Karya Seni Tekstil. Corak: Jurnal Seni Kriya. 